\title{
RELAKSASI OTOT PROGRESIF MENURUNKAN STRES KELUARGA YANG MERAWAT PASIEN GANGGUAN JIWA
}

\author{
Livana $\mathrm{PH}^{1 *}$, Novy Helena Catharina Daulima ${ }^{2}$, Mustikasari ${ }^{2}$ \\ 1. Program studi Keperawatan STIKES Kendal, Kendal 51311, Indonesia \\ 2. Fakultas Ilmu keperawatan Universitas Indonesia, Depok 16424, Indonesia \\ *E-mail: livana.ph@gmail.com
}

\begin{abstract}
Abstrak
Gangguan jiwa merupakan penyakit tidak menular yang menjadi masalah kesehatan masyarakat, baik di dunia maupun di Indonesia. Jumlah gangguan jiwa di kabupaten Kendal meningkat sehingga meningkatnya stres pada keluarga. Penelitian bertujuan untuk menilai efektifitas relaksasi otot progresif dalam menurunkan stres keluarga yang merawat pasien gangguan jiwa. Desain penilitian quasi eksperiment pre-post test with control group dengan 96 sampel secara purposive sampling, 48 kelompok intervensi dan 48 kelompok kontrol. Hasil penelitian relaksasi otot progresif sangat efektif menurunkan stres keluarga yang merawat pasien gangguan jiwa dibanding kelompok yang tidak mendapatkan perlakuan $(\mathrm{p}=0,001)$. Rekomendasi penelitian relaksasi otot progresif diberikan pada keluarga pasien gangguan jiwa untuk mengatasi stres keluarga dalam merawat pasien gangguan jiwa.
\end{abstract}

Kata kunci: relaksasi otot progresif, stres, keluarga pasien gangguan jiwa

\begin{abstract}
Effect of progressive muscle relaxation to the level of family stress in caring for clients of mental disorders in Psiciatry Polyclinic Regional General Hospital Kendal. Mental disorders are not contagious disease that is public health problem, both in the world and in Indonesia. In kendalthe number of mental disorders increase so increasing the level of family stress. The purpose of this study to identify the effect of progressive muscle relaxation on the level of family stress in caring for clients of mental disorders in Psiciatry Polyclinic Regional General Hospital Kendal. Quasi experiments research design pre-post test with control group with 96 sampelsby purposive sampling,48groups received therapyand 48 groups did not receive therapy. The results showed that a progressive muscle relaxation exercise significant difference between the stress levels in the group who received and did not receive therapy $(p=0.001)$. Tthis research did recommendated to families who are clients of mental disorders as aprimary care giver stress levels of families cope with caring for clients in mental disorders with progressive muscle relaxation therapy.
\end{abstract}

Keywords: progressive muscle relaxation, stress, client family mental disorder.

\section{Pendahuluan}

Gangguan jiwa merupakan penyakit tidak menular yang menjadi masalah kesehatan masyarakat, baik didunia maupun di Indonesia. Gangguan jiwa menurut Notosoedirdjo dan Latipun (2005) dimaknai sebagai adanya penyimpangan dari norma-norma perilaku, yang mencakup pikiran, perasaan, dan tindakan. Gangguan jiwa dapat terjadi tanpa mengenal usia, karena tingkat stres yang berlebihan akibat dari sesuatu yang mengganggu fisik dan psikis. Masyarakat seringkali memiliki persepsi negatif terhadap gangguan jiwa, mereka dianggap sebagai orang yang tidak waras, sinting dan ungkapan kasar lainnya.

Masyarakat menganggap kehadiran pasien gangguan jiwa terjadi akibat konstruksi pola pikir yang salah akibat ketidaktahuan pada tindakan sehingga tidak membantu kesembuhan pasien gangguan jiwa. Masyarakat percaya bahwa gangguan jiwa disebabkan oleh gangguan roh jahat, sebagian ada yang menuduh bahwa 
gangguan jiwa terjadi akibat guna-guna, kutukan atau hukuman atas dosanya. Kepercayaan yang salah ini akan merugikan pasien gangguan jiwa ataupun keluarganya sehingga pasien gangguan jiwa tidak mendapat pengobatan secara cepat dan tepat (Notosoedirjo \& Latipun, 2005). Masyarakat mempunyai penilaian negatif (stigma) terhadap pasien gangguan jiwa, dengan bereaksi emosional dan berperilaku diskriminasi yang menjadi stressor yang tidak kecil bagi keluarga pasien (Mubin, Hamid, \& Wiarsih, 2008).

Gangguan jiwa umumnya mengalami gangguan psikologis sebagai keluhan utama, sehingga berdampak terganggunya kebutuhan fisiologis (Kusumawati \& Hartono, 2010). Penyebab gangguan jiwa merupakan proses interaksi yang kompleks antara faktor organo-biologik, psikoedukatif, dan sosiokultural. Faktor organobiologik merupakan keadaan biologis atau jasmani yang dapat menghambat perkembangan individu, seperti kelainan gen, kurang gizi, dan penyakit, sehingga dapat memengaruhi seluruh aspek tingkah laku mulai dari kecerdasan sampai daya tahan terhadap stres. Faktor psikoedukatif meliputi aspek psikologis dan pendidikan seperti adanya trauma psikis pada masa kanak-kanak atau pola asuh yang salah. Faktor sosiokultural merupakan keadaan obyektif dari masyarakat yang berupa tuntutan sehingga menimbulkan tekanan pada individu (Bahar \& Syaify, 2013).

Menurut Videbeck (2008) ada tiga faktor yang menyebabkan gangguan jiwa, yaitu faktor individual, faktor interpersonal, faktor sosial dan budaya. Badan Kesehatan Dunia (WHO) memperkirakan bahwa sebanyak 450 juta orang di seluruh dunia menderita gangguan jiwa (Anna, 2012). Prevalensi gangguan jiwa di Indonesia saat ini masih cukup tinggi. Jumlah pasien gangguan jiwa di provinsi Jawa Tengah mencapai sebesar 2,3\% dari prevalensi gangguan jiwa berat nasional sebesar 1,7 per mil (Kemenkes, 2013). Jumlah gangguan jiwa di wilayah Kabupaten Kendal juga meningkat. Faktor utama yang menyebabkan peningkatan jumlah gang- guan jiwa adalah faktor ekonomi dan beban hidup karena ketidakmampuan untuk mengatasi emosi serta lemahnya dukungan sosial (Bappeda Kabupaten Kendal, 2012).

Hasil penelitian Andriani, Mubin, dan $\mathrm{PH}$ (2012) menunjukkan mayoritas keluarga yang memiliki anggota keluarga gangguan jiwa mengalami tingkat stres sedang sebesar $66,7 \%$. Cara untuk menunjang penyembuhan pasien gangguan jiwa, yaitu dengan mengurangi stres dan menambah kemampuan keluarga untuk menghindari dampak negatif stres dengan relaksasi otot progresif (Ramdhani \& Putra, 2008).

Relaksasi Otot progresif adalah suatu metode relaksasi yang paling sederhana dan mudah dipelajari dengan menegangkan dan merilekskan otot-otot tubuh (Richmond, 2013). Pada keluarga pasien gangguan jiwa yang mengalami stres dapat ditemukan satu atau lebih diagnosis keperawatan yang berkaitan dengan stres sehingga perlu intervensi yang berupa intervensi keperawatan generalis ataupun spesialis yang ditujukan untuk pasien sebagai individu, keluarga, dan kelompok (Stuart, 2009).

Hasil penelitian Hikmawati, Mubin, dan $\mathrm{PH}$ (2013) menunjukkan bahwa ada pengaruh hipnotis lima jari terhadap tingkat stres keluarga dalam merawat anggota keluarga gangguan jiwa sebesar $60 \%$. Gambaran tingkat stres yang dialami keluarga karena memikirkan bahwa pasien gangguan jiwa tidak ada perubahan, dan selalu ketergantungan dengan obat sehingga banyak dari keluarga yang merawat pasien gangguan jiwa mengalami gangguan tidur dan merasakan otot sakit seperti ditusuk-tusuk, pegal dan tegang. Sedangkan tindakan khusus untuk mengatasi respon fisiologis terhadap stres dengan relaksasi otot progresif belum pernah dilakukan. Oleh karena itu, peneliti tertarik untuk melakukan penelitian lebih lanjut tentang perbedaan tingkat stres keluarga yang merawat pasien gangguan jiwa yang mendapat dan yang tidak mendapat terapi relaksasi otot progresif di salah satu Poli Jiwa di sebuah rumah sakit di wilayah Jawa Tengah. 


\section{Metode}

Penelitian ini menggunakan desain quasi eksperiment dengan pendekatan Pre-Posttest with control group. Kriteria sampel penelitian yaitu keluarga inti, bisa membaca dan menulis, serta memiliki anggota keluarga yang mengalami gangguan jiwa. Sampel penelitian berjumlah 96 orang, diambil secara purposive sampling yaitu 48 orang kelompok intervensi dan 48 orang kelompok kontrol. Tempat penelitian dilakukan di poli RS suatu Kabupaten di Jawa Tengah.

Penelitian ini menggunakan prinsip etik yang meliputi menghormati martabat manusia (Respect for person), berbuat baik (Beneficence), tidak merugikan (non maleficence), dan keadilan (Justice) (Polit dan Hungler, 2001). Pengukuran tingkat stres pada saat pre dan post test menggunakan kuesioner Depression Anxiety Stress Scale 42 (DASS 42) dan buku kerja. Sebelum melakukan penelitian dilakukan uji lolos etik untuk kelayakan penelitian oleh tim komite etik Fakultas Ilmu Keperawatan Universitas Indonesia. Penelitian ini sudah melalui proses uji lolos etik. Selanjutnya peneliti menjelaskan tujuan dan manfaat penelitian kepada responden, jika responden bersedia diminta mengisi lembar persetujuan kesediaan menjadi responden yang ditandatangani dan selanjutnya dilakukan latihan relaksasi otot progresif hingga responden dianggap mengerti dan mampu mengikuti 15 gerakan secara berurutan sesuai dengan petunjuk dalam panduan yang diberikan.
Pelaksanaan terapi relaksasi otot progresif dilakukan mandiri oleh responden di rumah selama empat hari secara rutin, hari kelima peneliti mengunjungi rumah responden untuk mengumpulkan data. Setelah dilakukan mandiri oleh responden, lembar kuesioner dan buku kerja dikumpulkan oleh peneliti untuk dilakukan proses pengolahan data dengan terlebih dahulu dilakukan pengecekan ulang. Pengolahan data melalui tahapan editing, coding, scroling, processing, cleaning. Analisis data menggunakan perangkat lunak komputer dengan analisis statistik uji Chi-square.

\section{Hasil}

Tabel 1 menunjukkan bahwa hasil analisis ratarata umur responden dari kedua kelompok yang mendapat dan yang tidak mendapat terapi adalah 44,48 tahun, dengan standar deviasi 9,513. Umur termuda 26 tahun dan umur tertua 55 tahun. Sedangkan rata-rata lama merawat pasien gangguan jiwa pada kedua kelompok adalah 3,1 tahun, dengan standar deviasi 1,16. Lama merawat pasien gangguan jiwa terendah 1 tahun dan tertinggi 4 tahun. Sedangkan hasil analisis didapatkan nilai $\mathrm{p}=0,168(\mathrm{p}>0,05)$ yang menunjukkan bahwa tidak ada hubungan yang bermakna atau setara antara umur kelompok yang mendapat terapi dengan kelompok yang tidak mendapat terapi, sedangkan hasil analisis lama merawat pasien gangguan jiwa didapatkan nilai $\mathrm{p}=0,264(\mathrm{p}>0,05)$ yang menunjukkan bahwa tidak ada hubungan yang

Tabel 1. Distribusi dan Analisis Kesetaraan Umur dan Lama Merawat Pasien Gangguan Jiwa

\begin{tabular}{|c|c|c|c|c|c|c|c|}
\hline Variabel & $\mathrm{n}$ & Mean & Median & SD & Min-Maks & $\mathrm{R}$ & $\mathrm{p}$ \\
\hline \multicolumn{8}{|l|}{ Umur } \\
\hline Kelompok yang mendapat terapi & 48 & 44,04 & 45,5 & 9,392 & $26-55$ & $-0,202$ & 0,168 \\
\hline $\begin{array}{l}\text { Kelompok yang tidak mendapat } \\
\text { terapi }\end{array}$ & 48 & 44,92 & 47,5 & 9,713 & $26-55$ & & \\
\hline Total & 96 & 44,48 & 46,5 & 9,513 & $26-55$ & & \\
\hline \multicolumn{8}{|l|}{ Lama merawat pasien gangguan jiwa } \\
\hline Kelompok yang mendapat terapi & 48 & 3,04 & 4 & 1,22 & $1-4$ & $-0,165$ & 0,264 \\
\hline $\begin{array}{l}\text { Kelompok yang tidak mendapat } \\
\text { terapi }\end{array}$ & 48 & 3,15 & 4 & 1,09 & $1-4$ & & \\
\hline Total & 96 & 3,1 & 4 & 1,16 & $1-4$ & & \\
\hline
\end{tabular}


Tabel 2. Distribusi dan Analisis Kesetaraan Jenis Kelamin, Pendidikan, Status Perkawinan, Pekerjaan, dan Penghasilan

\begin{tabular}{|c|c|c|c|c|c|c|c|}
\hline \multirow[t]{2}{*}{ Variabel } & \multicolumn{2}{|c|}{$\begin{array}{l}\text { Kelompok yang } \\
\text { mendapat terapi }\end{array}$} & \multicolumn{2}{|c|}{$\begin{array}{c}\text { Kelompok yang tidak } \\
\text { mendapat terapi }\end{array}$} & \multirow[t]{2}{*}{ Total } & \multirow[t]{2}{*}{$\%$} & \multirow[t]{2}{*}{$\mathrm{p}$} \\
\hline & $\mathrm{f}$ & $\%$ & $\mathrm{f}$ & $\%$ & & & \\
\hline \multicolumn{8}{|l|}{ Jenis Kelamin } \\
\hline Laki-laki & 20 & 41.7 & 22 & 45,8 & 42 & 43,75 & \multirow[t]{2}{*}{0,845} \\
\hline Perempuan & 28 & 58,3 & 26 & 54,2 & 54 & 56,25 & \\
\hline \multicolumn{8}{|l|}{ Pendidikan } \\
\hline Tamat SD & 25 & 52,1 & 31 & 64,6 & 56 & 58,3 & \multirow{4}{*}{0,072} \\
\hline Tamat SMP & 5 & 10,4 & 4 & 8,3 & 9 & 9,4 & \\
\hline Tamat SMA & 14 & 29,2 & 11 & 22,9 & 25 & 26 & \\
\hline Tamat PT & 4 & 8,3 & 2 & 4,2 & 6 & 6,3 & \\
\hline \multicolumn{8}{|l|}{ Status Perkawinan } \\
\hline Belum menikah & 6 & 12,5 & 4 & 8,3 & 10 & 10,4 & \multirow{3}{*}{0,909} \\
\hline Menikah & 41 & 85,4 & 42 & 87,5 & 83 & 86,6 & \\
\hline Janda atau duda & 1 & 2,1 & 2 & 4,2 & 3 & 3 & \\
\hline \multicolumn{8}{|l|}{ Pekerjaan } \\
\hline Tidak Bekerja & 19 & 39,6 & 15 & 31,2 & 34 & 35,4 & \multirow[t]{2}{*}{0,720} \\
\hline Bekerja & 29 & 60,4 & 33 & 68,8 & 62 & 64,6 & \\
\hline \multicolumn{8}{|l|}{ Penghasilan } \\
\hline 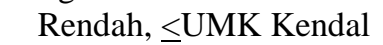 & 28 & 58,3 & 30 & 62,5 & 58 & 60,4 & \multirow[t]{2}{*}{1,000} \\
\hline Tinggi, > UMK Kendal & 20 & 41,7 & 18 & 37,5 & 38 & 39,6 & \\
\hline \multicolumn{8}{|c|}{ Tingkat stres sebelum pemberian terapi relaksasi otot progresif } \\
\hline Ringan & 11 & 22,9 & 12 & 25 & 23 & 24 & \multirow{2}{*}{0,430} \\
\hline Sedang & 37 & 77,1 & 36 & 75 & 73 & 76 & \\
\hline
\end{tabular}

bermakna atau setara antara lama merawat pasien gangguan jiwa pada kelompok yang mendapat dan yang tidak mendapat terapi relaksasi otot progresif.

Tabel 2 menunjukkan bahwa hasil analisis pada kelompok yang mendapat dan tidak mendapat terapi, mayoritas keluarga yang merawat pasien gangguan jiwa $56,25 \%$ berjenis kelamin perempuan, $58,3 \%$ pendidikan tamat $\mathrm{SD}, 86,6 \%$ menikah, $64,6 \%$ bekerja, dan $60,4 \%$ memiliki penghasilan kurang dari atau sama dengan UMK kabupaten Kendal serta $76 \%$ mengalami stres tingkat sedang sebelum pemberian terapi relaksasi otot progresif. Hasil analisis kesetaraan karakteristik jenis kelamin, pendidikan, status perkawinan, pekerjaan, penghasilan dan tingkat stres memiliki nilai $p>0,05$ sehingga dapat disimpulkan bahwa tidak ada perbedaan atau setara antara jenis kelamin, pendidikan, status perkawinan, pekerjaan, penghasilandan tingkat stres kelompok yang mendapat dan yang tidak mendapat terapi relaksasi otot progresif.

Hasil pada Tabel 3 didapatkan kelompok intervensi/ perlakuan setelah diberikan relaksasi otot progresif mengalami penurunan tingkat stres dibandingkan dengan kelompok kontrol. Terdapat perbedaan tingkat stres antara kelompok intervensi/ perlakuan dengan kelompok kontrol $(\mathrm{p}=0,000)$.

Pada Tabel 4 menunjukkan bahwa mayoritas jumlah responden pada kelompok yang mendapatkan terapi mengalami stres ringan sebanyak 38 orang. Sedangkan pada kelompok yang tidak mendapatkan terapi, responden yang mengalami stres ringan berjumlah delapan orang. 
Tabel 3. Perubahan Tingkat Stres Keluarga dalam Merawat Klien Gangguan Jiwa pada Kelompok yang Mendapat dan yang Tidak Mendapat Terapi Sebelum dan Sesudah Pemberian Terapi Relaksasi Otot Progresif

\begin{tabular}{|c|c|c|c|c|c|c|c|c|c|c|c|}
\hline & & \multirow{3}{*}{$\begin{array}{l}\text { Tingkat } \\
\text { stres }\end{array}$} & \multicolumn{6}{|c|}{ Sesudah Pemberian Terapi } & \multirow{2}{*}{\multicolumn{2}{|c|}{ Total }} & \multirow{3}{*}{$\mathrm{p}$} \\
\hline & & & \multicolumn{2}{|c|}{ Normal } & \multicolumn{2}{|c|}{ Ringan } & \multicolumn{2}{|c|}{ Sedang } & & & \\
\hline & & & $\mathrm{N}$ & $\%$ & $\mathrm{n}$ & $\%$ & $\mathrm{n}$ & $\%$ & $\mathrm{~N}$ & $\%$ & \\
\hline \multirow{6}{*}{$\begin{array}{c}\text { Sebelum } \\
\text { pemberian } \\
\text { terapi }\end{array}$} & Kelompok yang & Ringan & 9 & 18,7 & 2 & 4,2 & - & - & 11 & 22,9 & 0,000 \\
\hline & mendapat terapi & Sedang & 1 & 2,1 & 36 & 75 & - & - & 37 & 77,1 & \\
\hline & & Total & 10 & 20,8 & 38 & 79,2 & - & - & 48 & 100 & \\
\hline & Kelompok yang & Ringan & 1 & 2,1 & 1 & 2,1 & 10 & 20,8 & 12 & 25 & 0,159 \\
\hline & tidak mendapat & Sedang & 0 & 0 & 7 & 14,6 & 29 & 60,4 & 36 & 75 & \\
\hline & terapi & Total & 1 & 2,1 & 8 & 16,7 & 39 & 81,2 & 48 & 100 & \\
\hline
\end{tabular}

Tabel 4. Perbedaan Tingkat Stres Keluarga dalam Merawat Klien Gangguan Jiwa pada Kelompok yang Mendapat dan yang Tidak Mendapat Terapi Sesudah Pemberian Terapi Relaksasi Otot Progresif

\begin{tabular}{|c|c|c|c|c|c|c|c|c|c|c|}
\hline \multirow{3}{*}{$\begin{array}{l}\text { Kelompok yang } \\
\text { mendapat terapi }\end{array}$} & \multirow{3}{*}{ Tingkat stres } & \multicolumn{6}{|c|}{ Kelompok yang tidak mendapat terapi } & \multirow{2}{*}{\multicolumn{2}{|c|}{ Total }} & \multirow{3}{*}{$\mathrm{p}$} \\
\hline & & \multicolumn{2}{|c|}{ Normal } & \multicolumn{2}{|c|}{ Ringan } & \multicolumn{2}{|c|}{ Sedang } & & & \\
\hline & & $\mathrm{n}$ & $\%$ & $\mathrm{n}$ & $\%$ & $\mathrm{n}$ & $\%$ & $\mathrm{n}$ & $\%$ & \\
\hline & normal & 1 & 2,1 & 5 & 10,4 & 4 & 8,3 & 10 & 20,8 & 0,001 \\
\hline & ringan & 0 & 0 & 3 & 6,3 & 35 & 72,9 & 38 & 79,2 & \\
\hline & total & 1 & 2,1 & 8 & 16,7 & 39 & 81,2 & 48 & 100 & \\
\hline
\end{tabular}

Hasil analisis menunjukkan bahwa 30 orang $(78,9 \%)$ lebih banyak dibandingkan kelompok yang tidak mendapat terapi mengalami stres ringan. Hal ini menunjukkan bahwa terapi relaksasi otot progresif mampu menurunkan tingkat stres sebesar 78,9\% antara kelompok yang mendapat dan yang tidak mendapatkan terapi. Dapat disimpulkan bahwa ada perbedaan yang bermakna antara tingkat stres kelompok yang mendapat dan yang tidak mendapatkan terapi relaksasi otot progresif $(p=0,001)$.

\section{Pembahasan}

Hasil penelitian pada kelompok yang mendapat terapi menunjukkan bahwa terapi relaksasi otot progresif mampu menurunan tingkat stres sebesar $71 \%$ dengan nilai $\mathrm{p}=0,000$ yang berarti bahwa ada penurunan yang bermakna antara tingkat stres sebelum dan sesudah latihan relaksasi otot progresif selama empat hari secara rutin pada kelompok yang mendapatkan terapi. Sejalan dengan teori terkait relaksasi otot pro- gresif oleh Ramdhani dan Putra (2008) yang menyatakan bahwa relaksasi otot progresif merupakan suatu metode untuk membantu menurunkan tegangan sehingga otot menjadi rileks. Relaksasi otot progrsif bertujuan menurunkan tanda dan gejala terkait ansietas dan stres seperti ketegangan otot dan kesulitan tidur. Ketika tubuh dan pikiran rileks secara otomatis ketegangan yang membuat otot-otot mengencang akan diabaikan. Smeltzer dan Bare (2002) mengungkapkan bahwa relaksasi otot progresif mampu menurunkan tanda dan gejala fisiologis dan psikologis dari stres.

Hasil penelitian ini mendukung beberapa penelitian sebelumya antara lain yaitu Hamarno, Nurachmah, dan Widyastuti (2010) yang menyatakan bahwa terapi relaksasi otot progresif secara bermakna mampu menurunkan rata-rata tekanan darah sistolik. Chen, et al. (2009) menyatakan bahwa latihan relaksasi otot progresif secara rutin mampu menurunkan berbagai situasi stres. Shinde, Shinde, Khatri, dan Hande 
(2013) menyatakan bahwa latihan relaksasi otot progresif mampu mengurangi efek psikologis seperti stres dan ketegangan mental. Wilk dan Turkoski (2012) menyatakan bahwa latihan relaksasi otot progresif mampu menurunkan tingkat stres, tekanan darah, dan denyut jantung pada pasien rehabilitasi jantung. Supriati, Keliat, dan Nuraini (2010) menyatakan bahwa pelaksanaan terapi relaksasi otot progresif yang dilakukan selama 4 hari pada pasien gangguan fisik menunjukkan ada penurunan tingkat ansietas setelah pemberian terapi relaksasi otot progresif. Hashim dan Hanafi (2011) menunjukkan bahwa relaksasi otot progresif menginduksi respons suasana hati dalam mengatasi kebingungan, depresi, dan kelelahan. Oktavianis (2010) menyatakan bahwa relaksasi otot progresif juga dapat menurunkan tingkat stres biologis pada pengasuh lanjut usia.

Hasil penelitian ini sejalan dengan teori Edmund Jacobson pada tahun 1930-an yang menyatakan bahwa Relaksasi otot progresif dapat dilakukan untuk mengatasi berbagai keluhan responden yang berhubungan dengan stres seperti ansietas, sering gelisah, kurang nafsu makan, dan insomnia. Efektifitas relaksasi otot progresif merupakan hubungan antara ketegangan otot dengan ketegangan emosi, sehingga individu yang mengalami gangguan emosional maka secara otomatis individu tersebut menegangkan otot-otot tubuhnya (Vitahealth, 2004). Videbeck (2008) mengungkapkan bahwa individu yang memiliki koping adaptif dapat berada pada tingkat stres ringan, dan sebaliknya individu yang memiliki koping maladaptif maka individu tersebut masuk dalam rentang stres sedang hingga berat. Pendapat ini mendukung hasil penelitian yaitu latihan relaksasi otot progresif yang dilakukan selama empat hari secara rutin mampu menurunkan tingkat stres sebesar $71 \%$.

Pada saat melakukan terapi relaksasi ini, perhatian responden diarahkan untuk membedakan perasaan yang dialami saat kelompok otot dilemaskan dan dibandingkan ketika otot-otot dalam kondisi tegang. Relaksasi Otot Progresif bertujuan menurunkan kecemasan, stres, ketegangan otot dan kesulitan tidur. Kontraksi otot akan diikuti dengan relaksasi dari 15 kelompok otot (Berstein \& Borkovec, 2005; Kwekkeboom \& Gretarsdottir, 2006; conrad \& Roth, 2007; Supriati, Keliat, \& Nuraini, 2010; Alini, 2012).

Hal lain yang mendukung keberhasilan terapi relaksasi otot progresif pada penelitian ini adalah peneliti menggunakan empat tahap dalam pemberian terapi relaksasi otot progresif ini, yaitu peneliti mempraktekkan terlebih dahulu gerakan yang akan dilatih, kemudian responden diminta untuk mengulang gerakan yang sudah dilatih, kemudian ketika responden mampu mempraktekan kembali gerakan yang sudah dilatih tersebut, peneliti memberikan umpan balik berupa pujian kepada responden untuk menguatkan kemampuan responden melaksanakan terapi relaksasi otot progresif, setelah responden mampu melaksanakan 15 gerakan secara berurutan maka responden diminta untuk mengaplikasikannya secara mandiri di rumah secara rutin selama 4 hari berturut-turut dan responden diminta untuk mendokumentasikan setiap latihan gerakan relaksasi otot progresif di buku kerja yang telah peneliti sediakan. Pelaksanaa terapi relaksasi ini mendukung pendapat Richmond (2013) yang menyatakan relaksasi otot progresif merupakan metode relaksasi yang paling sederhana dan mudah dipelajari untuk merilekskan otot tubuh sehingga mampu mengurangi stres.

Berdasarkan hasil penelitian dan teori, peneliti berpendapat bahwa latihan relaksasi otot progresif secara rutin mampu menurunkan tingkat stres dibandingkan dengan sebelum melakukan tindakan terapi tersebut. Keberhasilan terapi relaksasi otot progresif pada penelitian ini disebabkan komitmen responden yang bersedia melakukan terapi relaksasi otot progresif secara rutin pagi setelah bangun tidur dan malam sebelum tidur selama empat hari secara berturut-turut yang difokuskan pada setiap sesi.

Pelaksanaan relaksasi otot progresif pada responden sebaiknya menggunakan posisi yang 
nyaman, dan semua item yang menghambat dilepas seperti kacamata, sepatu dan ikat pinggang, kemudian responden diminta untuk menutup mata, menempatkan kaki terpisah dengan nyaman, dan menempatkan tangan jauh dari tubuh dengan telapak tangan menghadap ke atas. Latihan ini sebaiknya dilakukan sebanyak tiga sesi, masing-masing sesi 10-20 menit dengan melakukan 15 gerakan yang berurutan pada sesi dua, pelaksanaan terapi yang dilakukan secara rutin pada pagi hari setelah bangun tidur dan pada malam hari sebelum tidur selama empat hari berturut-turut menunjukkan bahwa pelaksanaan terapi relaksasi mampu menurunkan tingkat stres sebesar 78,9\%, untuk mencapai maksimal (100\%) maka diperlukan waktu yang lebih lama untuk melaksanakan terapi relaksasi otot progresif yaitu sekitar 5 hingga 6 hari secara rutin. Jika waktu pelaksanaan relaksasi otot progresif ditingkatkan menjadi 5 hingga 6 hari secara berturutturut kemudian dikaitkan dengan hasil penelitian oleh Hamarno, Nurachmah, dan Widyastuti (2010) yang menunjukkan bahwa latihan relaksasi otot progresif yang dilakukan selama enam hari secara bermakna mampu menurunkan tekanan darah sistolik sebesar 16,65 mmHg $(p=0,000)$, maka peneliti berpendapat bahwa pelaksanaan terapi relaksasi otot progresif yang dilakukan selama lima hingga enam hari secara rutin akan menurunkan tekanan darah sistolik yang nantinya akan berkontribusi terhadap penurunan tingkat stres.

Hasil penelitian ini sependapat dengan penelitian yang dilakukan oleh Tobing, Keliat, dan Wardhani (2012) yang menyatakan bahwa pemberian terapi relaksasi otot yang dilakukan di rumah responden selama 10 minggu dengan 4 sesi latihan serta frekuensi latihan rutin 2-3 kali dalam seminggu ternyata mampu meningkatkan kemampuan relaksasi secara bermakna. Jika dibandingkan dengan hasil penelitian sebelumnya tersebut, hasil penelitian ini ternyata lebih efektif dan efisien dalam menurunkan tingkat stres karena pemberian terapi relaksasi otot progresif pada penelitian ini dilakukan dengan 3 sesi dan 4 hari secara rutin, ternyata efektif menurunkan tingkat stres secara bermakna sebesar $78,9 \%$. Latihan relaksasi otot progresif yang digunakan sebagai ketrampilsan koping mampu mengajarkan responden dalam meningkatkan perasaan rileks sehingga ketegangan sebagai respon stres dapat diatasi.

\section{Kesimpulan}

Ada perbedaan yang bermakna antara tingkat stres kelompok yang mendapat dan yang tidak mendapat relaksasi otot progresif. Hasil penelitian ini diharapkan menjadi evidence based practice bagi perawat spesialis jiwa dalam memberikan alternatif terapi spesialis pada keluarga pasien gangguan jiwa berat. Bagi pengembang ilmu hendaknya terapi relaksasi otot progresif dapat dikembangkan menjadi satu topik atau satu mata ajar bagi mahasiswa keperawatan dan kesehatan setelah diuji efektivitasnya. Penelitian lanjut dengan metode kualitatif perlu dilakukan untuk melihat sejauh mana efektifitas terapi relaksasi otot progresif mengurangi tingkat stres keluarga dalam merawat pasien gangguan jiwa berat (BA, MK, HR).

\section{Referensi}

Alini, A. (2012). Pengaruh terapi assertiveness training dan progressive muscle relaxation terhadap gejala dan kemampuan klien dengan perilaku kekerasaan di RS Dr. H. Marzoeki Mahdi Bogor (Tesis, tidak dipublikasikan). Fakultas Ilmu Keperawatan Universitas Indonesia, Depok - Jawa Barat.

Andriani, T., Mubin, F., \& PH, L. (2012). Gambaran tingkat stres pada keluarga yang memiliki pasien gangguan jiwa di RSUD Dr. $H$. Soewondo Kendal (Skripsi, tidak dipublikasikan). STIKes Kendal, Jawa Tengah.

Anna, L.K. (2012, Oktober 10). WHO: 450 juta orang menderita gangguan jiwa. Kompas. Diperoleh dari https://lifestyle.kompas.com/

Bahar, A., \& Syaify, A. (2013). Sehat \& Bugar selama berhaji. Depok: Penebar Swadaya. 
Bappeda Kabupaten Kendal. (2012). Pengembangan sistem informasi profil daerah Kabupaten Kendal tahun 2012. Kendal: Badan Perencanaan dan Pembangunan Daerah Kabupaten Kendal.

Berstein, A.D., \& Borkovec, S. (2005). The journal: New direction in progressive relaxation training a guidebook for helping. USA: Praeger Publisher USA.

Chen, W.C., Chu, H., Lu. R.B., Chou, Y.H., Chen, C.H., Chang, Y.C., O’Brien, A.P., \& Chou, K.R. (2009). Efficacy of progressive muscle relaxation training in reducing anxiety in patients with acute schizophrenia. Journal of Clinical Nursing: Complementary \& Alternative Medicine, 18 (15), 2187-2196. doi: 10.1111/j.1365-2702.2008.02773.x.

Conrad, A., \& Roth, W.T. (2007). Muscle relaxation for anxiety disorder: It works but how? Journal of Anxiety Disorder, 21 (3), 243-246.

Hamarno, R., Nurachmah, E., \& Widyastuti. (2010). Pengaruh relaksasi otot progresif terhadap penurunan tekanan darah pada klien hipertensi primer di Kota Malang. (Tesis, tidak dipublikasikan). Fakultas Ilmu Keperawatan Universitas Indonesia, Depok - Jawa Barat.

Hashim, H.A., \& Hanafi, A.Y.H. (2011). The effects of progressive muscle relaxation and autogenic relaxation on young soccer players' moodstates. Asian Journal of Sports Medicine, 2 (2), 99-105.

Hikmawati, R., Mubin, F., \& PH, L. (2013). Pengaruh pemberian hipnotis 5 jari terhadap tingkat stress pada keluarga dalam merawat anggota keluarga gangguan jiwa berat di RSUD dr. H. Soewondo Kendal (Skripsi, tidak dipublikasikan). STIKes Kendal, Jawa Tengah.

Kemenkes RI. (2013). Profil kesehatan provinsi Jawa tengah tahun 2012. Jakarta: Pusat data dan informasi Kementrian kesehatan RI.

Kusumawati, F \& Hartono, Y. (2010). Buku ajar keperawatan jiwa. Jakarta: Salemba Medika.
Kwekkeboom, K.L., \& Gretarsdottir, E. (2006). Systematic review of relaxation interventions for pain. J Nurs Scholarsh, 38 (3), 269-277.

Mubin, M.F., Hamid, A.C.S., \& Wiarsih, W. (2008). Pengalaman stigma pada keluarrga dengan klien gangguan jiwa di Kota Semarang: Studi fenomenologi (Tesis, tidak dipublikasikan). Fakultas Ilmu Keperawatan Universitas Indonesia, Depok - Jawa Barat.

Notosoedirjo, M., \& Latipun, L. (2005). Kesehatan mental, konsep, dan penerapan. Malang: UMM Press.

Oktavianis, D. (2010). Efektivitas relaksasi otot progresif untuk menurunkan tingkat stres padapengasuh lanjut usia di Panti Werdha $X$ (Tesis, tidak dipublikasikan). Fakultas Psikologi Universitas Airlangga, Surabaya.

Ramdhani, N., \& Putra, A.A. (2008). Pengembangan multimedia relaksasi. Yogjakarta: Bagian Psikologi klinis Fakultas Psikologi UGM.

Richmond, R.L. (2013). A guide to psychology and its practice: Progressive muscle relaxation. Diperoleh dari http://www.guidetopsycholo gy.com/pmr.htm.

Shinde, N., Shinde, K.J., Khatri, S.M., \& Hande, D. (2013). Immediate effect of jacobson's progressive muscular relaxation in hypertension. Indian Journal of Physiotherapy and Occupational Therapy, 7 (3), 234-237. 10.5958/j.0973-5674.7.3.098

Smeltzer, S.C., \& Bare, B.G. (2002). Buku Ajar Keperawatan Medikal Bedah Brunner \& Suddarth. Jakarta: EGC.

Stuart, G.W. (2009). Principles and practice of psychiatric nursing (9th Ed.). St. Louis: Mosby.

Supriati, L., Keliat, B.A., \& Nuraini, T. (2010). Pengaruh terapi tought stopping dan progressive muscle relaxation terhadap ansietas pada pasien dengan gangguan fisik di RSUD Dr. Soewondo Madiun (Tesis, tidak dipublikasikan). Fakultas Ilmu Keperawatan Universitas Indonesia, Depok - Jawa Barat. 
Tobing, D.L., Keliat, B.A., \& Wardhani, I.Y. (2012). Pengaruh progresive muscle relaxation dan logoterapi terhadap perubahan ansietas, depresi, kemampuan relaksasi, dan kemampuan memaknai hidup pasien kanker di RS Dharmais Jakarta (Tesis, tidak dipublikasikan). Fakultas Ilmu Keperawatan Universitas Indonesia, Depok - Jawa Barat.

Videbeck, S.L. (2008). Buku ajar keperawatan jiwa (alih bahasa: R. Komalasari, A. Hany). Jakarta: EGC.
Vitahealth. (2004). Hipertensi. Jakarta: Gramedia Pustaka Utama.

Wilk, C., \& Turkoski, B. (2012). Progressive muscle relaxation in cardiac rehabilitation: A pilot study. Rehabilitation Nursing, 26 (6), 238-242. 